\section{N-Hydroxylierung von 2-Aminofluoren durch Lebermikrosomen}

Aromatische Amine werden durch Lebermikrosomen von Ratten bei Anwesenheit von TPNH und Sauerstoff am Stickstoff oxydiert. Hierbei entsteht nach unseren Versuchen primär das betreffende Hydroxylaminderivat ${ }^{2}$. CRAMER, MILLHR und MILLER ${ }^{3}$ konnten im Urin von Ratten, die längere Zeit mit 2-Acetylaminofluoren gefuittert wurden, N-Hydroxy-2-acetylaminofluoren nachweisen. Schon vorher hatte KIESE nach Anilingaben im Blut von Hunden Nitrosobenzol gefunden, wenn das Blut unter Zusatz eines Oxydationsmittels extrahiert wurde4.

Wir haben untersucht, ob 2-Aminofluoren auch durch Lebermikrosomen am Stickstoff hydroxyliert werden kann. 2-Aminofluoren bildet nämlich im Organismus Methämoglobin. In Ansätzen aus Mikrosomen und TPNH, die yerschiedene Amine oxydierten ${ }^{5}$, konnte aber nicht sicher N-Hydroxy-2-aminofluoren nachgewiesen werden. Da die Oxydationsgeschwindigkeit ziemlich linear mit der Konzentration an TPNH zunimmt ${ }^{2}$, erhöhten wir die TPNH-Konzentration auf $2 \mu M / \mathrm{ml}$ Ansatz und konnten nun das N-Oxydationsprodukt auffinden und bestimmen.

Tetrachlorkohlenstoffextrakte solcher Ansätze nach $Z$ ugabe von $\mathrm{Fe}^{+++}$zeigten dasselbe Spektrum wie synthetisch gewonnenes 2-Nitrosofluoren ${ }^{6}$.

$\mathrm{Da}$ nach Untersuchungen von HuLTIN ${ }^{1}{ }^{14} \mathrm{C}$-markiertes 2-Aminofluoren in Ansätzen von Lebermikrosomen und
TPNH wesentlich schneller an Proteine gebunden wird als Anilin, dürfte die wirkliche Hydroxylierungsgeschwindigkeit höher sein, zumal Aminofluoren in den Ansätzen nicht gelöst, sondern als Suspension vorliegt. Das hydroxylierende System in Mikrosomen führt neben der $\mathrm{N}$ Hydroxylierung gleichzeitig Hydroxylgruppen an verschiedenen Positionen von 2-Aminofluoren ein. Solche Phenolgruppen sind aber längst nicht so reaktionsfähig wie die Hydroxylaminverbindung.

Summary. Enzymatic N-hydroxylation of 2-aminofluorene has been achieved with rat liver microsomes in the presence of TPNH and $\mathrm{O}_{2}$.

\section{H. UEHLEKE*}

Pharmakologisches Institut der Universilät Tübingen (Deutschland), 31. Juli 1961.

1 H. Uenteke, Arch. exp. Path. Pharmak. 241, 150 (1961).

2 H. Unhleke, V. Int, Congr. Biochem, Moskau 1961, Abstr. p. 399 (Pergamon Press, London 1961).

s J. W. Cramer, J. A. Miller und E, C. Miller, J. biol Chem. 235, $885(1960)$.

4 M. KIESE, Arch. exp. Path. Pharmak. 235, 354 (1959).

S. Miese und H. Uehle Ke, Arch. exp. Path. Pharmak., im Druck.

- R. R. Holmes und R. P, Bayer, J. Amer, chem. Soc. 82,3354 (1960).

7 T. Hultin, Exp. Cell Res. 18, 112 (1959).

\section{The Role of Calcium and Zinc in the Electrical and Mechanical Responses of Frog Sartorius Muscle}

Much interest has been focussed upon calcium as a link in the excitation-contraction process ${ }^{1-8}$. It is, however, uncertain what aspects of skeletal muscle function are critically dependent upon the presence of calcium, i.e., whether calcium is essential to preserve the excitability of the membrane or whether some later stage in the excitation-contraction process is affected. The present study was aimed at elucidating the relationships between membrane potential, action potential and mechanical responses in single fibres and whole muscle in the absence of calcium. It was also found of interest to employ the same techniques to compare the effects of physiological concentrations of zinc with those of calcium.

Methods. Sartorius muscle of $R$. temporaria was used at a temperature of $0.5-2^{\circ} \mathrm{C}$. The isometric contractions of single surface fibres within the intact muscle were recorded by means of an RCA transducer, having a sensitivity of approximately $1 \mathrm{mg}$. The single fibres were stimulated by passing current intracellularly through a microelectrode, which was also used to measure resting potentials. The action potential was also recorded intracellularly in response to external stimulation with small bipolar platinum electrodes. Phosphate buffered Ringer's solution, containing $1.8 \mathrm{~m} M \mathrm{Ca}$ was used. All glassware used, after ordinary washing, was treated with $5 \mathrm{M} \mathrm{HCl}$, immediately followed by de-ionised water.

Results. Effects of Ca-lack. After removal of calcium from the bathing solution, the twitch and tetanus responses of the whole muscle declined gradually and were abolished in 2-3 h. EDTA $(0.1 \mathrm{~m} M)$ was always added to the 'Ca-free' solution but it was found that the loss of responses followed a similar time course in $0.01 \mathrm{mM}$ Ca solutions without EDTA. Mean resting potentials of surface fibres were approximately $50 \mathrm{mV}$ (range $25-60 \mathrm{mV}$ ) when mechanical responses had disappeared. Membrane potentials declined steadily by approximately $15 \mathrm{mV} / \mathrm{h}$. Thus the loss of mechanical response could be accounted for by a progressive loss of excitable fibres due to the decrease of the resting membrane potentials. In order to test whether this is the sole mechanism, mechanical and electrical responses of single surface fibres were recorded before and after removal of calcium from the bath.

Twitch responses from a large number of ventral surface fibres followed the same time course closely and the variation of peak tensions (5-120 mg) was consistent with the range of fibre cross sections. A mean peak tension of $34 \mathrm{mg}$ per fibre was found in Ca-Ringer's solution. After $1 / 2 \mathrm{~h}$ in Ca-free solution, some fibres failed to give propagated responses. Within the period $1 / 2-11 / 2 h$ after removal of calcium, $10 \%$ of the tested fibres were inexcitable and the mean peak tension of excitable fibres fell to $30 \mathrm{mg}$. Within the period $11 / 2^{1}-2^{1} / 2$ hours, $55 \%$ of the tested fibres were inexcitable and the peak tension of the responding fibres fell to $14 \mathrm{mg}$. The time course of the twitches was not significantly altered. When calcium $(1.8 \mathrm{mM})$ was reintroduced to the bath, substantial recovery of twitches occurred. After $2 \mathrm{~h}$, the mean peak tension had recovered to $24 \mathrm{mg}$ per fibre. The single fibres failed to respond to stimulation when their resting potentials were lower than $60 \mathrm{mV}$. This critical level has been found in Ca-Ringer's solution when fibres were depolarised with potassium ${ }^{8}$. It is concluded that even before individual fibres have

1. V. Heilbrun, An Outline of General Physiology, 3rd. Ed. (Saunders, Philadelphia 1952).

2. Sannow, Yale J. biol. Med. 25, 176 (1952)

* R. Niedergerke, J. Physiol. 134, 584 (1956).

4. M. Shanes, Pharmacol. Rev. 10, 165 (1958).

5 K. A. P. Edman and H. O. Schild, Nature 190, 350 (1961).

- P. A. Robertson, Nature 186, $316(1960)$

${ }^{7}$ G. B. Frank, J. Physiol. 151,518 (1960).

R. P. Durbin and D. H. Jenkinson, J. Physiol, 15\%, 90 (1961).

D. W. Grieve, Ph. D. Thesis: London University (1961). 